\title{
Towards zero-waste airports: a case study of Istanbul Airport
}

\author{
İsmail Özbay ${ }^{1}\left[\right.$ [D $\cdot$ Nebil Arda Gokceviz ${ }^{1}$
}

Received: 21 March 2021 / Accepted: 16 September 2021 / Published online: 20 October 2021

(c) Springer Japan KK, part of Springer Nature 2021

\begin{abstract}
In this day and age, an important indicator of sustainable waste management is zero-waste index. Zero-waste approach is adopted by many organizations in different sectors. In this context, implementation of sustainable waste management at airports, which have become the most vibrant centers of the transportation sector in the globalizing world, is one of the important environmental issues. In this study, the activities carried out in the Istanbul airport in 2019-2020 within the scope of sustainable waste management were evaluated within the framework of zero-waste approach. For this purpose, waste characterizations for different zones in the airport have been presented. When the methods used in the disposal of the wastes were examined, it was seen that recycling (43-49\%) and landfilling (50-57\%) took the first place. The results of the study reveal that the pandemic restrictions implemented in 2020 have caused significant differences in the amount and composition of waste generated. The highest decrease in waste generation occurred in Zone A where terminal activities are located, with $76 \%$. This change was also reflected in the zero-waste index determined depending on the waste management strategies applied, and the values calculated for 2019 and 2020 were found to be 0.35 and 0.26 , respectively.
\end{abstract}

Keywords Airports $\cdot$ Characterization $\cdot$ Pandemic $\cdot$ Recycling $\cdot$ Waste management $\cdot$ Zero-waste index

\section{Introduction}

Air travel has become one of the fastest, safest, efficient and comfortable modes of transport nowadays [1]. Journeys to distant places take place in a shorter time and this situation provides humanity with very important advantages in both cultural and commercial areas. The ever-increasing traffic in aviation creates an impetus for the increase of operations by providing safe and better service [2]. About 4.3 billion passengers used the airline in 2018, according to the International Civil Aviation Organization [3]. Airports, on the other hand, become an important means of global air transport where both passengers and aircraft are hosted 24/7 [4].

As airports grow and/or their operations increase, they create more environmental impacts, but there are also opportunities to be more sustainable [5]. A significant amount of waste is generated as a result of various activities carried out at airports, and this is considered to be one of the most important environmental issues of air transport. Airports

İsmail Özbay

iozbay@kocaeli.edu.tr

1 Department of Environmental Engineering, Faculty of Engineering, Kocaeli University, 41380 Kocaeli, Turkey prefer innovative policies such as "zero waste" in order to reduce the environmental impact of the wastes generated as a result of operations, to provide economic benefits from these wastes, if possible, and to comply with stricter rules [4, 6]. Sustainability is the most important key word in the future roadmap of airports and thus more efficient airports that consume less resources will emerge [7]. The most important environmental issues to be considered under the sustainability topic of airports are noise pollution, air pollution and emission management, efficient energy use, waste management and protection of biodiversity [8]. Among these topics, solid waste management and waste disposal have prevailing importance for environmental management of the global airline industry. According to international air transport data, 5.7 million tons of cabin waste was produced in the sector in 2017, and this waste volume can be duplicated in the next 10 years [9]. It is mandatory to have an appropriate waste management system at airports to prevent contamination of airport sites and to prevent the attraction of wildlife that may adversely affect the safety of operations [10]. Failure to manage organic wastes effectively may cause an increase in greenhouse gas (GHG) emissions that contribute to global warming [11]. In addition, since airports are local organizations, they should follow a policy in line with national / 
local waste management regulations and targets. Depending on these reasons, researches on waste management practices and strategies at airports have been getting increasing attention.

A good and feasible integrated waste management system should plan how to manage waste from source to the end product with the cradle to grave principle. In solid waste management applications, the strength of each driver and depth of interaction with other drivers exhibit significant variations according to types of waste, utilized disposal methods and even economic conditions [12]. Municipalities, tourism facilities, universities, factories and similar institutions that are waste producers today are working on the zero-waste strategy in waste management [13-17]. The zero-waste strategy is based on preventing waste generation and promoting recycling, so the waste should not be disposed of by landfill or incineration [6]. The major objective of zero-waste approach is to conserve natural resources by redesigning production process of the industry and adjusting the consumption behaviors of people [18].

Since waste management in airports is environmentally important, researches on the subject have gained attention in recent years. Baxter et al. examined the waste management practices between 2002 and 2015 at Kansai International Airport in detail and evaluated Air New Zealand's waste management program and strategies through the data collected from different sources [4, 6]. Blanca-Alcubilla et al. have examined the results of the "Zero Cabin Waste" project realized with the European Union life program for Madrid Barajas airport [19, 20]. Parameshwar evaluated solid waste management strategies at Bangalore International Airport between 2009 and 2011 [21]. Pitt and Smith researched waste management practices at United Kingdam airports considering the data provided from 6 airports operated by BAA (formerly the British Airports Authority) [22]. Dos Santos et al. evaluated the waste management at Congonhas Airport statistically using the fuzzy mathematical model [23]. Sarbassov et al. analyzed the composition of urban solid wastes produced at Astana International Airport and evaluated different waste management scenarios in terms of greenhouse gas emissions [24]. Suhaimi et al. investigated the factors affecting the strategic efficiency of solid waste management in Kuala Lumpur International Airports [25]. Tofalli et al. analyzed the characterization of wastes generated by passengers during the flight based on the data of airlines using Larnaca's International Airport [26]. As can be seen from the studies, there is no study on waste management strategies in airports within the framework of the zero waste concept.

The aim of this study was to present the roadmap to be followed in the creation of zero waste strategies in airports with the case study of Istanbul airport, which is the largest airport in Turkey in terms of both passenger capacity and service network. For this purpose, waste characterization was carried out in different sources and the efficiency of the applied waste management plan was evaluated with the calculated waste diversion rate and zero-waste index values.

\section{Materials and method}

\section{Presentation of the studied airport}

Istanbul airport, which is the only airport on the European side of Istanbul, is $35 \mathrm{~km}$ away from the city center and aims to increase its competitive power by adopting the airport city concept on the way to becoming a global center. The airport, where the first flights started in October 2018, opened officially in April 2019. It has an area of approximately 7650 hectares, is expected to be the largest airport in the world in terms of passenger traffic with an annual passenger capacity of 200 million passengers when fully completed. At the end of 2019, it was registered as the 14th airport serving the most passengers [27].

\section{Characterization of the solid wastes}

The characterization study was made with samples taken from Atatürk Airport, the predecessor of Istanbul Airport. In this study, samples taken from 17 different points were used for waste characterization which was performed according to ASTM-D52231. The wastes, collected from trolley, terminal, office and catering, were kept at separate points. Then waste samples were mixed sufficiently to ensure homogeneous composition. Enough amount of waste was taken from this mixture to fill the measuring container with a volume of $0.5 \mathrm{~m}^{3}(1 \times 1 \times 0 \times 5 \mathrm{~m})$. In order to calculate the amount of waste according to flight lengths, this measuring cup was not used for the waste coming from the aircraft. All the waste generated during the flight was used in characterization.

In the separation process, wastes are classified in 18 categories according to the European Commission's "Methodology for the Analysis of Solid Waste (SWA-Tool)". Three different categories which are long flights (flights lasting more than $4 \mathrm{~h}$ ), short flights (flights less than $4 \mathrm{~h}$ ) and flights without free catering have been created for samples taken from aircraft.

In order to determine the content of wastes generated during the flight, a characterization process was carried out on samples taken from 7 different flights in total: three types of International-Long Haul-Free Catering (IF-LH-FC), International-Short Haul-Free Catering (IF-SH-FC), International-Short Haul-Paid Catering (IF-SH-PC), Domestic-Free Catering (DF-FC) and Domestic-Paid Catering (DF-PC). More detailed characterization was performed for international long flights due to higher waste generation. 
Food unused during the flight is collected on trolleys and sent back to catering companies. Food returned is classified as waste by catering companies. In order to determine the organic load potential of trolley wastes, characterization studies were carried out with 2 different samples, both in domestic and international. Samples taken from the catering companies are important participants of the waste compositions during characterization studies. In addition, wastes belonging to the airline company headquarters kitchen are included in this category. Thus, a total of 4 characterization studies ( 2 for catering companies and 2 for airline company kitchens) were performed for this part on different dates. Day and night periods were evaluated individually for characterization of terminal wastes. In addition, the compositions of the wastes coming from the offices of airline and cargo companies have been revealed. Characterization results have been graphed considering the cumulative values.

\section{Determination of waste recycling rate and zero-waste index}

Waste conversion rate is one of the main indicators used to measure the performance of waste management systems. Waste diversion rate can be defined as the proportion of waste that is recycled or composted (recyclables) instead of being disposed by incineration or landfilling (garbage). The following equation is used to calculate the waste diversion rate [28]:

Diversion rate $=\frac{\text { Weight of recyclabes }}{\text { Weight of garbage }+ \text { Weight of recyclabes }}$ managed by different systems $\mathrm{j}$ ( $\mathrm{j}=$ composted, recycled, etc.), $S F_{i j}=$ Substitution factor for different waste streams ( $i=$ organic, paper, plastic, etc.) for different management systems ( $j=$ compost, recycle, etc.) based on their virgin material replacement efficiency, $G W S$ (ton/year) = Total amount of waste managed ( $i=1$ to $n$, all waste streams).

Zero waste index and waste diversion rate values were calculated based on actual waste data sent to the composting facility, licensed institutions (paper-cardboard, plastic, glass, metal), incineration plant and landfill. Substitution factors for different waste streams have been accepted in the light of data obtained from facility authorities.

\section{Results and discussion}

\section{Dynamics of passenger and cargo for İstanbul airport}

Figure 1 shows the total number of local and international passengers in Istanbul airport in 2019 and 2020. It is seen that international passengers were $75.4 \%$ and $68.2 \%$ of total passengers, respectively, in 2019 and 2020. These ratios demonstrate the importance of the airport in terms of international passenger traffic. In 2019, the Istanbul airport reached 75 million passengers with the high acceleration in the increase of passenger transportation. There was a $2.8 \%$ increase in passenger transpor-

$100 \%$
The 'waste diversion rate' is a numerical indicator that defines the efficiency of waste management system. However, the diversion rate may become inadequate to describe the rate of processed material that actually reduces resource consumption [29]. The zero-waste index, on the other hand, allows to measure environmental benefits (material substitution efficiency, energy and water savings, prevention of greenhouse gas emission, etc.) of management systems [28]. In the zero waste approach, it is targeted to use same materials repeatedly until optimum level of consumption. If reuse is not possible, the materials can be recycled or recovered from the waste stream. By this way, consumption of natural sources can be minimized [30]. Zero-waste index can be formulated as in Eq. (2) as follows.

$Z W I=\frac{\sum_{i-1}^{n}\left(W M S_{i j} \times S F_{i j}\right)}{\sum_{1}^{n} G W S}$,

where $Z W I=Z$ Zero-waste index, $W M S_{i j}$ (ton/year) = Amount of waste streams $i$ ( $i=$ organic, plastic, paper, metal, etc.) tation in January 2020 compared to the same period of the previous year. However, monthly passenger transport data decreased gradually after March 2020 due to the impacts of the Covid-19 pandemic. Applied restrictions has resulted a sharp decline in the number of passengers. As the restrictions were partially cancelled in July 2020, primarily domestic flights started again and the number of monthly passengers started to exceed 1 million. The total number of passengers in 2020 decreased by $66 \%$ compared to 2019 and remained at the level of 23.2 million due to the pandemic restrictions.

Istanbul Airport has been designed as an important transportation base with its geopolitical location, new and highly capable infrastructure, and more importantly, having both land, air and sea routes. The amount of cargo hosted in the airport has increased from 590,962 tons to 869,289 tons in 2019-2020 period. These results have indicated that cargo transportation has grown in quantity despite the pandemic. 
Fig. 1 Monthly domestic and international passenger traffics for 2019 and 2020 at İstanbul Airport

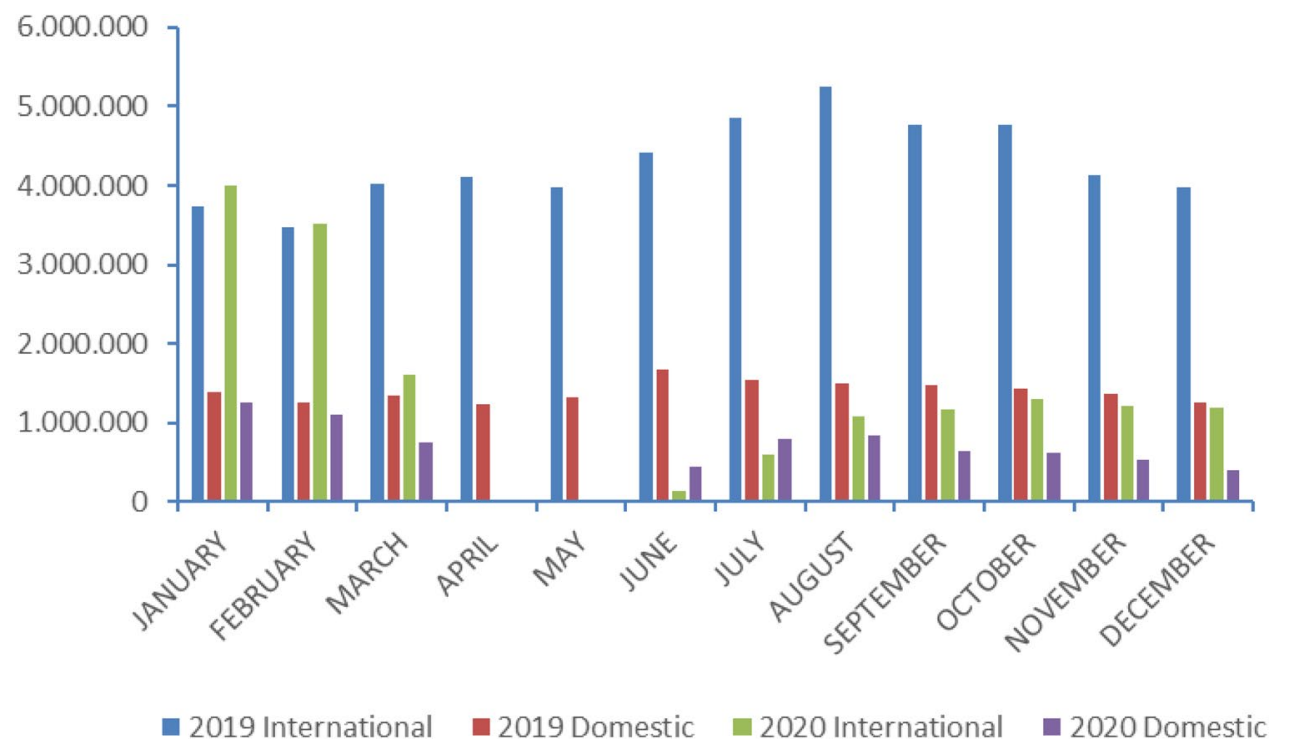

\section{Waste collection system of the airport}

There are many businesses serving in different lines within the airport. Since the enterprises that provide similar services are located close to each other in the facility, it is possible to collect the waste generation zones within the airport in three classes according to their location and functions.

Zone A (Passenger Terminal \& Carpark): these are the areas with the highest density at airports. The main waste density at the passenger terminals stems from the mobile population. Waste collection boxes are placed in suitable places to collect the wastes created by the dense crowd. Waste collection bins are designed with 4 cells for packaging recycling, paper recycling, glass recycling and other wastes. The wastes accumulated in the recycling bins are often collected with wheeled vehicles during the day. The collected wastes are first accepted in special containers in the waste rooms at the terminal and subjected to pre-separation. The wastes that are ready to be shipped are sent to the waste sorting facility suitable for their waste classes. Organic wastes are sent directly to the compost facility.

Zone B (Landside Buildings): infrastructure of airports is divided as air and land side. There are support buildings and technical buildings in landside airports. Energy centers, wastewater treatment plant, aircraft fuel farm, catering facilities, government buildings (governorship, police, gendarmerie, etc.) are in this category. The largest waste producer of this category is catering facilities. Organic waste from catering companies is sent directly to the composting facility. Wastes from all other buildings are collected in 4 categories: recyclable, glass, organic and other.

Zone C (Airside Buildings): aircraft and their serving facilities are located in this zone. Ground handling buildings and facilities, hangars, air traffic control towers and cargo companies are located on the airside. Cargo companies are the largest waste producer of airside outdoor buildings. Pallets (plastic and wood) and packaging materials used especially for the transportation of large-sized cargo lead the wastes from this zone. In addition, there are hazardous and industrial wastes from hangars in this zone.

Although waste management at Istanbul airport is managed within itself in the mini-city mode, since it is a part of the urban system, it should follow a policy in line with the strategies and objectives of local governments responsible for the management of the city's waste. In Istanbul, wastes are collected in 8 different transfer stations where no separation process is performed and then transferred to the waste collection facilities located in the Asian and European regions. Recyclable portion of the waste stream is sent to the material recovery facility while the organic portion is transferred to the composting facility. The remaining wastes are also landfilled and disposed [31]. Similarly, the wastes generated at the airport are categorized as organic, recyclable and domestic wastes according to the present waste management plan (Fig. 2). As can be seen from the figure, the main difference of waste management at airports from urban waste management is that the separation process is carried out more effectively at the source. Organic wastes separated at source in dining halls and catering are directly sent the composting facility. Packaging and other recyclable materials collected in recycling bins are separated according to their types in the waste separation facility with a feeding capacity of 28 tons/h and then recycled by licensed companies. Domestic wastes, on the other hand, are separated as recyclable, flammable and biodegradable in the waste separation facility. While combustible wastes are considered as energy sources in RDF facilities, biodegradable wastes are disposed of in the urban waste landfill. In order to develop 
Fig. 2 Waste management strategies followed in Istanbul Airport
Organic Waste
From Catering and Kitchens $\begin{gathered}\text { Decomposition } \\ \text { at Source }\end{gathered}$ at Source
Compost Facility

To licensed

Institutions by

Type

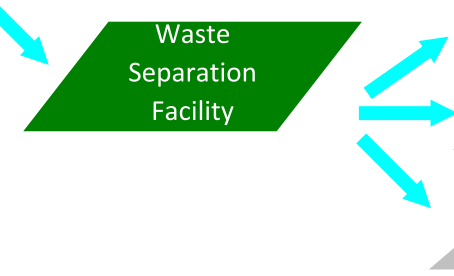

Incineration

Landfill

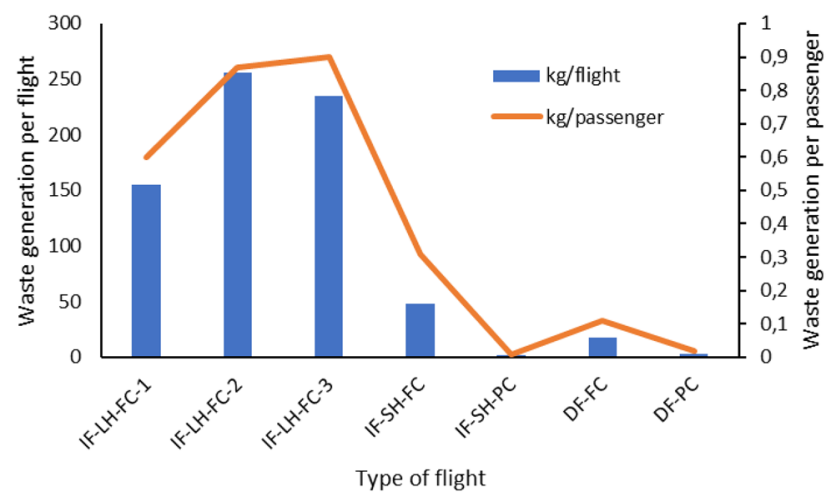

Fig. 3 Waste generation amounts for different types of flights

strategies suitable for the zero-waste approach at airports, the amount of waste generated at the facility and its characterizations should be presented accurately. The waste formation and applied disposal methods were evaluated based on the waste data delivered to the disposal facilities for years 2019 and 2020.

\section{Waste generation and characterization from flights}

One of the most important sources of waste at airports is mainly due to flights with free refreshments. Waste formation per passenger were determined for the flights considering flight distances and catering conditions (Fig. 3).

High waste generation (155-235 kg/flight) was observed due to free catering on long-distance flights abroad. While the waste generation per passenger is in the range of $0.6-0.9 \mathrm{~kg}$ on long-distance flights with free catering, this ratio decreases to 0.31 levels on short-haul flights. On shorthaul domestic flights, on the other hand, waste generation per flight is reduced by approximately $83 \%$, as catering is paid. As can be seen from the figure, waste generation per passenger decreases to the level of $0.02 \mathrm{~kg}$ on flights where catering is paid. Blanca-Albucilla et al. (2019) indicated that the length of flight and the number of menus offered in long flights are the main factors affecting waste generation [16]. The increase in the number of free treats, especially on longdistance flights has caused a remarkable increase in waste generation. Therefore, a positive correlation was observed between waste generated per passenger and flight time.

Results of characterization studies showed that the rate of recyclable packaging waste from all flights except for domestic short-distance flights with paid catering is over $45 \%$. The other prominent waste types are combustible wastes with ratios in the range from 5 to $29 \%$ and liquid wastes with ratios from 3 to $12 \%$. The high percentage of packaging wastes may be due to catering services including packaged food and drinks during long-flights. Approximately $65 \%$ of organic waste is generated on domestic shorthaul flights with paid catering, while this rate varies between 6 and $17 \%$ on flights with free catering. The main reason for this can be explained by the fact that a very small amount of waste (approximately $3 \mathrm{~kg}$ per flight), is generated due to the fee being paid, and that most of the waste is the food that passengers bring with them. Since the food and drinks left over from the catering service on the aircraft are sent to the relevant catering company, they are considered as waste from their facilities.

\section{Characterization of waste production from airport activities}

Istanbul Airport City, which includes hotels, offices, shopping and entertainment areas, hospitals, mosques, education buildings and logistics areas, is designed to be used by the passengers using the Airport, domestic and international visitors. For this reason, it is very important to identify and effectively manage waste sources in sustainable airport cities such as Istanbul Airport. Waste production from catering companies and kitchens, trolleys, terminal and offices of cargo and airline companies that continue their activities in Istanbul Airport was also examined in this study.

The composition of wastes from trolleys is different for domestic and international flights. Organic wastes with a 
ratio of $56.27 \%$ and recyclable materials with a ratio of $18.96 \%$ are densely observed in wastes originating from international trolleys, while $37.57 \%$ liquid waste and $33.88 \%$ organic wastes stand out in domestic trolleys. When the wastes originating from domestic and international trolleys are compared according to their percentage by weight, organic wastes with a ratio of $54 \%$, recyclable materials with a ratio of $18 \%$, liquid wastes with a ratio of $12 \%$ and finally, $15 \%$ other combustible wastes draw attention (Fig. 4(a)). Composition of the wastes originating from catering companies and kitchens is given in Fig. 4(b). While the rate of organic waste originating from catering companies is in the range of $30-42 \%$; this rate is in the range of $60-79 \%$ for kitchen wastes of airline company. The ratio of recyclable material content of catering and kitchen wastes is $14 \%$ which is remarkably lower than organic waste ratio (47\%).

(a)

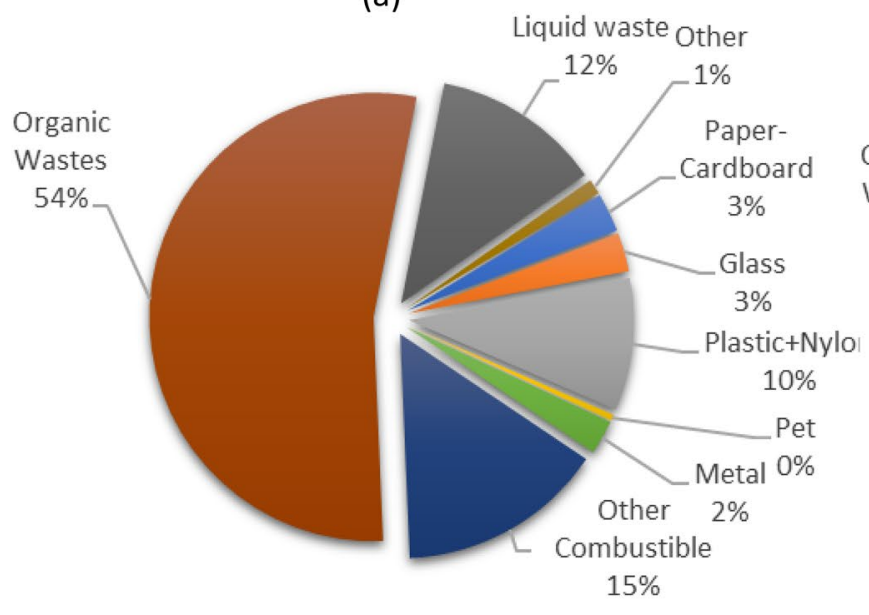

(c)

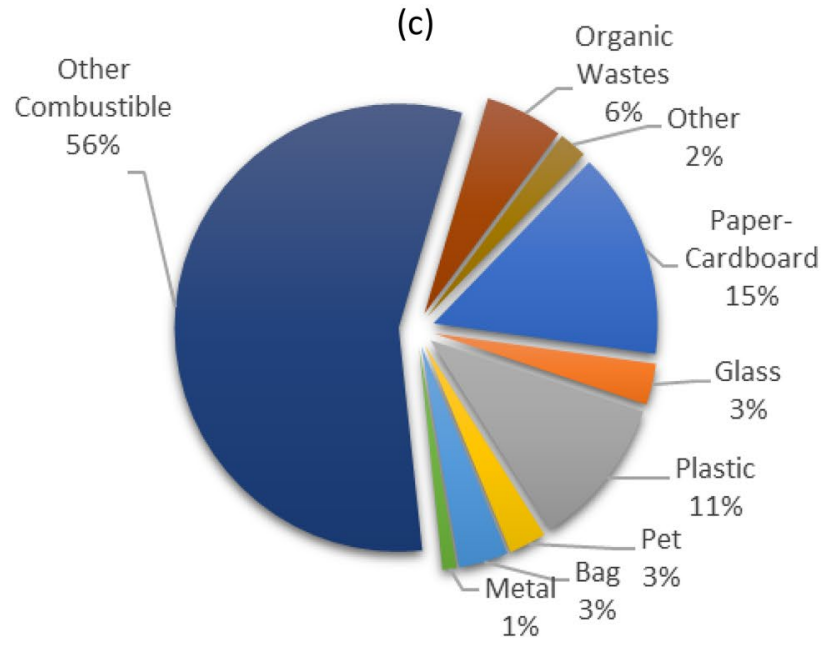

In order to determine the composition of terminal wastes, two separate studies were conducted for day and night period, and cumulative results are given in Fig. 4(c). It is clearly seen that terminal wastes are mainly consisted of combustible and recyclable materials with ratios of $56 \%$ and $36 \%$, respectively. Characterization results for the wastes originating from the offices of cargo and airline companies are given in the Fig. 4(d). When waste compositions of the two office types were compared, it was found that the main difference was in the amount of organic wastes. The fraction of organic wastes for airline companies' office is $23.45 \%$ while this ratio was lower for cargo companies' office (7.56\%). Recyclable materials with an average of $43 \%$ and combustible wastes with an average of $43 \%$ have been identified as important components in the general composition of office waste. (b)

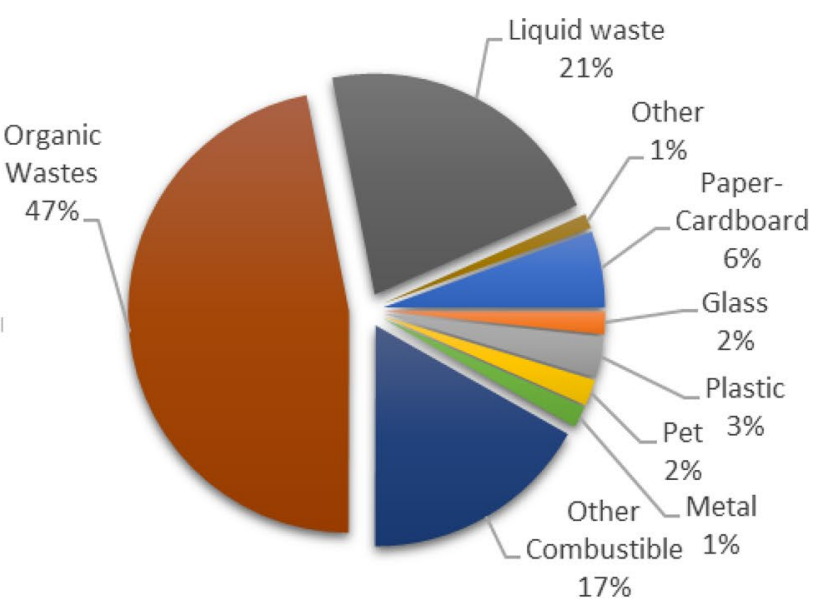

$17 \%$

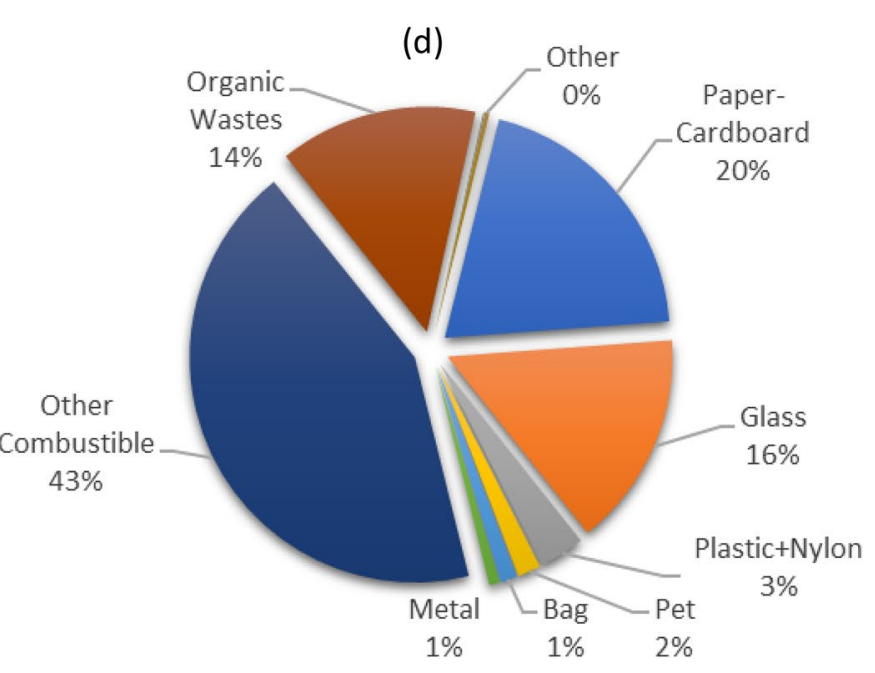

Fig. 4 Composition of wastes from a Trolley, b Catering company and kitchen, $\mathbf{c}$ Terminal, $\mathbf{d}$ Cargo office and airline company 


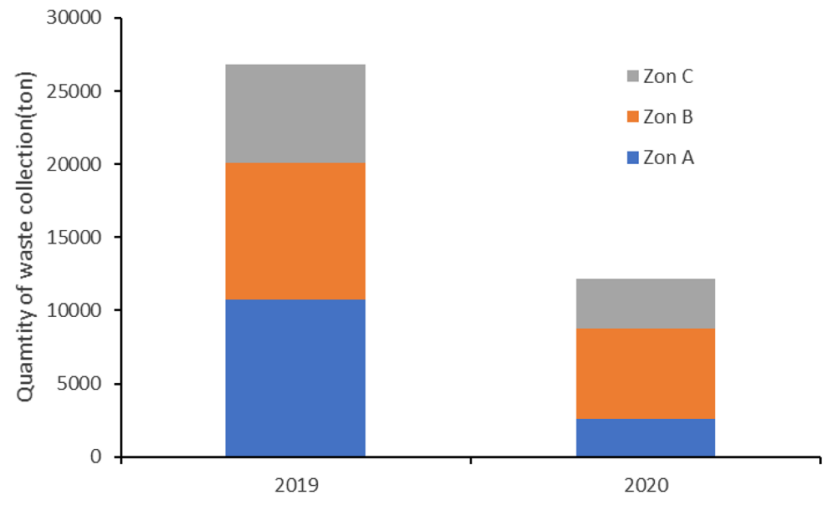

Fig. 5 Zonal waste collection at Istanbul Airport

\section{Quantity of waste generation and zero-waste index for Istanbul Airport}

The amount of waste collected from different zones of Istanbul airport is given in Fig. 5. As can be seen from the figure, waste generation decreased by approximately $55 \%$ in 2020 . Before the pandemic in $2019,40 \%$ of the waste collected originated from zone A, 35\% from zone B and 25\% from zone $\mathrm{C}$ whereas in 2020 , when restrictions were imposed due to the pandemic, these rates were decreased to $21 \%, 51 \%$ and $28 \%$, respectively.

While significant decreases occurred in all zones compared to the previous year, the highest waste reduction occurred in Zone A (76\%), where the terminal is located. The decrease in total waste amounts can be attributed to the decrease in the number of passengers, as well as due to the pandemic restrictions. For this reason, it would be more meaningful to evaluate the waste formations per passenger. In 2019 and 2020, waste generation per passenger was determined to be 0.39 and $0.52 \mathrm{~kg}$, respectively. It is thought that the amount of waste generation, which increases with the decrease in the number of passengers, is due to the increase in the efficiency of the consumption of personnel working in airport activities. When these values are compared with other airports, waste generation per passenger at Istanbul airport is similar to those in the airports in Japan, Brazil and UK (Table 1).

When waste disposal methods are examined, the organic wastes separated at the source are sent directly to the composting facility, while the other wastes are recycled after being processed in the decomposition facility or disposed in incineration or landfilling facilities. As can be seen from Table 2, landfilling and recycling are widely preferred in the management of waste generated at the airport.

Waste diversion rate was calculated to evaluate the efficiency of implemented waste management strategies and it was determined as 52\% and $44 \%$ for 2019 and 2020 , respectively. This situation was caused by the cessation
Table 1 Waste per passenger at different airports

\begin{tabular}{lll}
\hline Airport & $\begin{array}{l}\text { Waste generation } \\
(\mathrm{kg} / \text { passenger })\end{array}$ & References \\
\hline Naples International Airport & 0.14 & {$[32]$} \\
Astana International Airport & 0.24 & {$[24]$} \\
Kansai International Airport & $0.43-0.80$ & {$[4]$} \\
Congonhas Airport & $0.50-4.00$ & {$[23]$} \\
Aberdeen Airport & 0.26 & {$[22]$} \\
Edinburgh Airport & 0.21 & \\
Glasgow Airport & 0.35 & \\
Heathrow Airport & 0.41 & \\
Gatwick Airport & 0.50 & \\
Stansted Airport & 0.30 & This study \\
Southampton Airport & 0.23 & \\
İstanbul Airport & $0.39-0.52$ & \\
\hline
\end{tabular}

of passenger circulation, which is an important source of the recyclable waste composition in the port, due to the restrictions in flight activities due to the pandemic. While the amount of waste disposed of by storing during the pandemic process decreased by approximately $47 \%$, the amount of recyclable waste decreased by $61 \%$.These results show that the restrictions imposed due to the pandemic cause the diversion rates of waste to decrease.

Although the concept of zero-waste, which defines the ideal waste and research management, is important for sustainable waste management, it is a difficult process to perform for an organization or community [30]. The zerowaste index of Istanbul airport was determined as 0.36 and 0.26 for 2019 and 2020, respectively. Achieving the zerowaste target is possible by developing waste management strategies in a way to reduce the tendency towards landfilling and incineration technologies. When examined waste management in terms of waste diversion rate and zero-waste index in Adelaide city between 2003 and 2010, the composting efficiency was increased from 61.5 to $79.9 \%$, but since the recycling targets were insufficient, the zero-waste index was only increased to 0.40 [29]. As it can be understood from here, zero-waste strategies are applications that require extensive planning and long processes to increase recycling. At Istanbul airport, strategies should be developed to increase the rate of recycling and composting by reducing the amount of mixed waste by increasing the separation efficiency at the source.

\section{Conclusions}

Istanbul Airport is one of Europe's most important airports with growing flight network and passenger capacity day by day. The major aim of this work was to evaluate 
Table 2 Waste diversion rate and zero waste index for waste management systems in Istanbul Airport

\begin{tabular}{|c|c|c|c|c|c|c|}
\hline \multirow[t]{2}{*}{ Indicators } & \multirow[t]{2}{*}{ Waste type } & \multirow{2}{*}{$\begin{array}{l}\text { Virgin material } \\
\text { substitution efficiency } \\
\text { (tonnes) }\end{array}$} & \multicolumn{2}{|l|}{2019} & \multicolumn{2}{|l|}{2020} \\
\hline & & & $\begin{array}{l}\text { Managed of waste } \\
\text { materials (tonnes) }\end{array}$ & $\begin{array}{l}\text { Substitution from } \\
\text { material (tonnes) }\end{array}$ & $\begin{array}{l}\text { Managed of Waste } \\
\text { materials (tonnes) }\end{array}$ & $\begin{array}{l}\text { Substitution from } \\
\text { material (tonnes) }\end{array}$ \\
\hline \multirow[t]{6}{*}{ Recycling } & Paper & $0.84-1.00^{\mathrm{a}}$ & 5256.76 & 4731.08 & 1413.75 & 1272.38 \\
\hline & & $0.90^{\mathrm{b}}$ & & & & \\
\hline & Glass & $\begin{array}{l}0.90-1.00^{\mathrm{a}} \\
0.98^{\mathrm{b}}\end{array}$ & 644.64 & 631.75 & 202.5 & 198.45 \\
\hline & Metal & $\begin{array}{l}0.79-0.96^{\mathrm{a}} \\
0.85^{\mathrm{b}}\end{array}$ & 96.10 & 81.69 & 34.45 & 29.28 \\
\hline & Plastic & $\begin{array}{l}0.90-0.97^{\mathrm{a}} \\
0.95^{\mathrm{b}}\end{array}$ & 2321.51 & 2205.44 & 766.45 & 728.13 \\
\hline & Mixed & $\begin{array}{l}0.25-0.45^{\mathrm{a}} \\
0.30^{\mathrm{b}}\end{array}$ & 5493.45 & 1648.04 & 2920.45 & 876.14 \\
\hline Compost & Organic & $\begin{array}{l}0.60-0.65^{\mathrm{a}} \\
0.60^{\mathrm{b}}\end{array}$ & 181.42 & 108.85 & 29.40 & 17.64 \\
\hline Landfill & Mixed & 0.00 & $12,803.05$ & - & 6814.37 & - \\
\hline İncineration & Mixed & 0.00 & 15.00 & - & - & - \\
\hline Total waste managed & & & $26,811.93$ & & $12,181.37$ & \\
\hline Waste diversion rate $(\%)$ & & & 0.52 & & 0.44 & \\
\hline Zero Waste Index & & & 0.35 & & 0.26 & \\
\hline
\end{tabular}

${ }^{a}$ Range of localized substitution factor [28]

${ }^{\mathrm{b}}$ Substitution factors for waste separation facility, compost facility and licensed institutions in the airport

the efficiency of waste management practices at this airport based on waste diversion rate and zero-waste index.

When the waste generation from flights is examined, waste generation in the range of $0.6-0.9 \mathrm{~kg} /$ passenger flight due to free catering on long-distance flights shows a decrease over 50\% in short-distance flights with free catering. On short-haul paid flights, on the other hand, it decreases to $0.02 \mathrm{~kg} /$ passenger flight level. Locations with the highest percentage of organic waste at airports are catering establishments, kitchens and trolleys (>40\%), while the locations with the highest percentage of recyclable waste are terminals and offices (40\%). In waste management strategies, while the rate of waste sent to recycling was over $43 \%$, the rate of waste sent to composting remained at very low levels $(<1 \%)$. Since the study covers the 2019-2020 periods, it also shows the effect of pandemic restrictions on waste management. In 2020, due to the restrictions, waste generation rates decreased by $55 \%$. However, when evaluated in terms of waste generation per passenger, there was an increase of $33 \%$ compared to 2019 . Waste diversion rate was $44 \%$ in 2020 , while the zero-waste index was determined to be 0.26 . Results of this study concluded that politics on pollution prevention are still insufficient and global approaches are also required besides institutional applications in order to achieve the zero waste targets at airports.

The efficiency of the zero waste approach can be improved by application of short, medium and long term plans and monitoring the percentage of meeting the targets to be set. The data obtained from this study clearly revealed the points that should be focused while developing the strategy. As airports host people from different points with very different cultures, it is seen that consumption behaviors that increase the amount of waste can be changed by economic practices rather than educational activities. Separation at source by utilizing industrial practices should be encouraged at airports to achieve zero waste targets. As a result, it is seen that the development of efforts to prevent free catering flight policies within the scope of zero-waste strategies will significantly reduce the amount of waste from flights. In order to increase the waste diversion rate and zero-waste index, efforts should be made to separate the waste to be composted and recyclable waste at the source more effectively and to increase the recycling rates. It is observed that the pandemic restrictions caused a decrease in the efficiency of waste management due to external service practices. Increasing alternatives in waste management or reducing external dependency will contribute to preventing these declines. It is expected that outputs of this study will enlighten the concerned authorities to improve waste management strategies at other airports.

Supplementary Information The online version contains supplementary material available at https://doi.org/10.1007/s10163-021-01308-2. 


\section{References}

1. Clemes MD, Gan C, Kao TH, Choong M (2008) An empirical analysis of customer satisfaction in international air travel. Innovative Mark 4(2):49-62

2. Wang Y, Zhan J, Xu X, Li L, Chen P, Hansen M (2019) Measuring the resilience of an airport network. Chin J Aeronaut 32(12):2694-2705. https://doi.org/10.1016/j.cja.2019.08.023

3. ICAO (2018) Presentation of 2018 air transport statistical results. International Civil Aviation Organization Web. https://www.icao. int/annual-report-2018/Pages/the-world-of-air-transport-in-2018statistical-results.aspx. Accessed 8 February 2021.

4. Baxter G, Srisaeng P, Wild G (2018) Sustainable airport energy management: the case of Kansai International Airport. Int J Traffic Transp Eng 8(3):334-358. https://doi.org/10.7708/ijtte.2018.8(3). 07

5. Asinjo DA (2011) Environmental management at sustainable airport models. Southern Illinois University Carbondale (Dissertation)

6. Baxter G (2020) Sustainable airline waste management: a case study of air New Zealand's waste management Programs and Strategies. Int J Traffic Transp Eng 10(3):351-370. https://doi. org/10.7708/ijtte.2020.10(3).07

7. Kaya SK, Erginel N (2020) Futuristic airport: a sustainable airport design by integrating hesitant fuzzy SWARA and hesitant fuzzy sustainable quality function deployment. J Clean Prod 275:123880. https://doi.org/10.1016/j.jclepro.2020.123880

8. Santa SLB, Ribeiro JMP, Mazon G, Schneider J, Barcelos RL, Guerra JBSOD (2020) A Green Airport model: proposition based on social and environmental management systems. Sustain Cities Soc 59:102160. https://doi.org/10.1016/j.scs.2020.102160

9. IATA (2021) International catering waste: a case for smarter regulation, International Air Transport Association Web. https://www. iata.org/contentassets/821b593dd8cd4f4aa33b63ab9e35368b/ summary-icw-case-for-smarter-regulation.pdf. Accessed 22 May 2021.

10. ICAO (2021) Waste Management at Airports. International Civil Aviation Organization Web. https://www.icao.int/environmentalprotection/documents/waste_management_at_airports_booklet. pdf. Accessed 22 May 2021.

11. Munster M, Ravn H, Hedegaard K, Juul N, Söderman ML (2015) Economic and environmental optimization of waste treatment. Waste Manag 38:486-495. https://doi.org/10.1016/j.wasman. 2014.12.005

12. Agamuthu P, Khidzir KM, Hamid FS (2009) Drivers of sustainable waste management in Asia. Waste Manag Res 27:625-633. https://doi.org/10.1177/0734242X09103191

13. Lugo M, Ail SS, Castaldi MJ (2020) Approaching a zero-waste strategy by reuse in New York City: challenges and potential. Waste Manag Res 38(7):734-744. https://doi.org/10.1177/07342 42X20919496

14. Dileep MR (2007) Tourism and waste management: a review of implementation of "Zero Waste" at Kovalam. Asia Pac J Tour Res 12(4):377-392. https://doi.org/10.1080/10941660701823314

15. Mason IG, Brooking AK, Oberender A, Harford JM, Horsley PG (2003) Implementation of a zero waste program at a university campus. Resour Conserv Recycl 38:257-269. https://doi.org/10. 1016/S0921-3449(02)00147-7

16. Pattanaik L, Duraivadivel P, Hariprasad P, Naik SN (2020) Utilization and re-use of solid and liquid waste generated from the natural indigo dye production process - a zero waste approach. Bioresour Technol 301:122721. https://doi.org/10.1016/j.biortech. 2019.122721

17. Parashar A, Jin Y, Mason B, Chae M, Bressler DC (2016) Incorporation of whey permeate, a dairy effluent, in ethanol fermentation to provide a zero waste solution for the dairy industry. J Dairy Sci 99:1859-1867. https://doi.org/10.3168/jds.2015-10059

18. Ayeleru OO, Okonta FN, Ntuli F (2018) Municipal solid waste generation and characterization in the City of Johannesburg: a pathway for the implementation of zero waste. Waste Manage 79:87-97. https://doi.org/10.1016/j.wasman.2018.07.026

19. Blanca-Alcubilla G, Bala A, Hermira JI, De-Castro N, Chavarri R, Perales R, Barredo I, Fullana-I-Palmer P (2018) Tackling international airline catering waste management: life zero cabin waste project. State of the art and first steeps. Detritus 3:159-166. https://doi.org/10.31025/2611-4135/2018.13698

20. Blanca-Alcubilla G, Roca M, Bala A, Sanz N, De Castro N, Fullana-i-Palmer P (2019) Airplane cabin waste characterization: Knowing the waste for sustainable management and future recommendations. Waste Manage 96:57-64. https://doi.org/10. 1016/j.wasman.2019.07.002

21. Parameshwar HK (2011) Solid waste management in airports: a case study of Bangalore International Airport. Proceedings of International Conference on Green Technology and Environmental Conservation. IEEE Publisher, India, pp 152-158

22. Pitt M, Smith A (2003) Waste management efficiency at UK airports. J Air Transp Manag 9:103-111. https://doi.org/10.1016/ S0969-6997(02)00063-7

23. Dos Santos AJ, Mancini SD, Roveda JAF, Ewbank H, Roveda SRMM (2020) A fuzzy assessment method to airport waste management: a case study of Congonhas Airport, Brazil. J Air Transp Manag 87:101838. https://doi.org/10.1016/j.jairtraman.2020. 101838

24. Sarbassov Y, Venetis C, Aiymbetov B, Abylkhani B, Yagofarova A, Tokmurzin D, Anthony EJ, Inglezakis VJ (2020) Municipal solid waste management and greenhouse gas emissions at international airports: a case study of Astana International Airport. J Air Transp Manag 85:101789. https://doi.org/10.1016/j.jairtraman. 2020.101789

25. Suhaimi HA, Nor FM, Nasir SM (2019) The strategic effectiveness on implementation of solid waste management at Kuala Lumpur International Airport Politeknik and Kolej Komuniti. J Soc Sci Humanit 4(1):76-84

26. Tofalli N, Loizia P, Zorpas AA (2018) Passengers waste production during flights. Environ Sci Pollut Res 25:35764-35775. https://doi.org/10.1007/s11356-017-0800-x

27. Deveci M, Çiftçi ME, Akyurt IZ (2020) Strategical analysis and the impact of Istanbul Airport on Turkish Airlines. J Econ Soc Dev 7(1):71-80

28. Zaman AZ, Lehmann S (2013) The zero waste index: a performance measurement tool for waste management systems in a 'zero waste city.' J Clean Prod 50(1):123-132. https://doi.org/10.1016/j. jclepro.2012.11.041

29. Zaman AZ (2014) Measuring waste management performance using the 'Zero Waste Index': the case of Adelaide Australia. J Clean Prod 66:407-419. https://doi.org/10.1016/j.jclepro.2013. 10.032

30. Song Q, Li J, Zeng X (2015) Minimizing the increasing solid waste through zero waste strategy. J Clean Prod 104:199-210. https://doi.org/10.1016/j.jclepro.2014.08.027

31. Ayvaz-Cavdaroglu N, Coban A, Firtina-Ertis I (2019) Municipal solid waste management via mathematical modeling: a case study in İstanbul Turkey. J Environ Manage 244:362-369. https://doi. org/10.1016/j.jenvman.2019.05.065

32. Miedico M (2018) Sustainable growth management at Naples international airport, Italy. WIT Trans Ecol Environ 215:233-240. https://doi.org/10.2495/EID180211

Publisher's Note Springer Nature remains neutral with regard to jurisdictional claims in published maps and institutional affiliations. 